\title{
Perang Wacana Islam Liberal Versus Islam Fundamental
}

\author{
Herdi Sahrasad \\ Dosen Sekolah Pasca Sarjana dan peneliti senior Pusat Studi Islam dan Kenegaraan (PSIK) Universitas \\ Paramadina
}

\begin{abstract}
One of the new phenomenon in religious discourse in Indonesia is the discourse war between liberal Islam versus fundamental Islam. The birth of Liberal Islam has attracted response from fundamental Islam in which the latter use oftenly a hard, crude and rouge language to corner the liberal muslim.bThis article try to trace back the wrestle and contestation between liberal and fundamental muslim in public sphere to snatch away structure of political opportunity. Whether or not this contestation continues, to some extent this depend on the liberal and fundamental muslim themselves in spreading their influence and teaching in the grassroot level and public sphere.
\end{abstract}

Kata Kunci: Islam; fundamental; liberal

\section{Pendahuluan}

Dalam pelbagai percakapan dengan para aktivis HMI (Himpunan Maha- siswa Islam), IMM (Ikatan Mahasiwa Muhammadiyah) dan PII (Pelajar Islam Indonesia), saya mendapat pertanyaan, mengapa berminat mengkaji kembali perang wacana (polemik) Jaringan Islam Liberal (JIL) versus Islam fundamental?

Langkah apakah yang dikerjakan oleh Jaringan Islam Liberal (JIL) versus Islam fundamental untuk mengatasi kemiskinan, ketidakadilan, korupsi dan pelanggaran HAM di negeri ini? Adakah sumbangsih kedua mazhab Islam itu untuk rakyat kebanyakan yang ditipudaya oleh elite penguasa dan para kapitalis? Bukankah program kedua kelompok Islam itu dikhawatirkan menjadi proyek -bisnis agamall untuk mencari dana juga?

Pertanyaan-pertanyaan para aktivis santeri itu mengusik penulis untuk menelusuri perang wacana dan tarik-ulur JIL dan Islam fundamental lebih jauh, dalam batas-batas kemampuan yang ada. Tulisan ini merupakan analisa diskursus dan catatan awal (pendahuluan) ihwal Islam liberal versus liberal dari berbagai teks, perdebatan di ruang publik dan sumber kepus- takaan.

\section{Fatwa MUI}

Musyawarah Nasional Majelis Ulama Indonesia (MUI) ke VII Agustus tahun 2005 mengeluarkan fatwa yang mengharamkan pluralisme yang mengang- gap semua agama sama, mengharamkan sekularisme dan liberalisme beserta semua turunannya. Kalangan MUI dan Islam fundamental mengemukakan bahwa -amuk\| muncul dari kelompok liberal atas fatwa tersebut, dan pertarungan belum lagi sampai ke final. Mula-mula, serangan kalangan Islam Liberal atas fatwa MUI itu telah menjadi kontroversi yang luar biasa. Pada waktu itu pernyataan Ulil Abshor Abdalla (koordinator Jaringan Islam Liberal-JIL) yang menganggap fatwa MUI itu -konyol dan tololl, dinilai kalangan MUI sebagai kata-kata tidak pantas. Ulil kemudian meminta maaf terhadap MUI. Sementara statemen M. Dawam Rahardjo (cendekiawan Muslim/tokoh ICMI) yang mengatakan bahwa fatwa MUI itu memecah belah masyarakat dan menimbulkan keresahan dan karena itu MUI harus 
dibubarkan, merupakan kritik pedas atas fatwa MUI itu. Pernyataan Ulil dan Dawam menimbulkan reaksi balik kaum Islam Fundamental yang merasa dilecehkan. Perkembangan ini berbarengan dengan fatwa MUI untuk mela- rang gerakan Ahmadiyah. Akibatnya, rangkaian peristiwa-peristiwa itu men- jontrongkan umat Islam -baik itu kalangan Fundamental maupun Liberal- ke dalam kontroversi dan ketegangan.2

yang sedang dirintis di Indonesia. Demokrasi menjadi terancam oleh fatwa itu karena tiga soal yang diha- ramkan oleh MUI itu sesungguhnya merupakan pilar utama demokrasi.

Dawam Rahardjo menilai dasar keputusan MUI itu ironis dan bukan kesa- lahpahaman, melainkan ketidakpahaman MUI atas sekularisme, liberalisme dan pluralisme (disingkat oleh kaum Islam Fundamental sebagai Sepilis, istilah berkonotasi pelecehan dan plesetan

$=$ 'Sipilis'", penyakit kelamin yang berbahaya) ${ }^{1}$

Kalangan Islam Liberal menilai, fatwa MUI itu akan mengancam fondasi dasar bagi proses demokratisasi, sesuatu yang dicita-citakan oleh reformasi, sehingga musuh reformasi bukan hanya otoritarianisme, otokrasi dan korupsi-kolusi-nepotisme, melainkan juga oleh absolutisme tafsir agama, yang merasa memiliki kebenaran mutlak dan menganggap yang lain sesat. $^{2}$

Dalam konteks globalisasi dewasa ini, ada kecenderungan kuat bahwa Islam di Indonesia cenderung kian liberal, sebagaimana diamati cukup lama oleh Greg Barton9 dalam arti makin menerima gagasan demokrasi, pluralisme dan HAM. Yang musti dipahami kita adalah bahwa Barat/AS mengapresiasi Islam Liberal, namun sangat takut kepada Islam Fundamental, sehingga masyarakat Barat/AS banyak menghujat kaum fundamentalis Islam sebagai biang kerok kekerasan dan terorisme. Padahal, terorisme negara oleh AS/Barat-lah-sebagaimana diungkap Noam Chomsky_yang mengilhami munculnya aksi teror balasan oleh kaum Muslim terhadap AS/Barat seperti dalam kasus serangan bom WTC 11 September 2001, bom Spanyol 2004, bom Bali 2002, dan teror bom di London 7 Juli 2005.

Bernard Lewis pernah menyatakan, pada abad KE-20, ada yang salah pada dunia Islam. Dibandingkan dengan rivalnya, Kristen, dunia Islam kini men- jadi miskin, lemah, dan bodoh. Sejak abad KE-19, dominasi Barat terhadap dunia Islam tampak jelas. Barat menginvasi kaum Muslim dalam setiap aspek kehidupan, bukan hanya pada aspek publik, tetapi --yang lebih menyakitkan-- juga dalam aspek-aspek pribadi. Namun, masyarakat Barat tetap saja melihat Islam sebagai momok (scourge) bagi Barat. ${ }^{3}$

Seyogyanya, kaum Muslim melakukan introspeksi atas kondisinya dan tidak terlalu menunjukkan sikap menunduk atau cari muka terhadap AS/Barat.12 Dalam hubungan ini, Islam Liberal mendapat bantuan AS/Barat untuk menyebarluaskannya dalam bingkai pluralisme dan demokrasi, sementara Islam Fundamental yang sering diasosiasikan dengan Pan-Islamisme di Arab dan bantuan Arab Saudi/Timur Tengah, dianggap sebagai

\footnotetext{
${ }^{1}$ Ahmad Sahal, -MUI dan Fatwa Antidemokrasi.॥

${ }^{2}$ Ahmad Sahal, -MUI dan Fatwa Antidemokrasi.

${ }^{3}$ Kalau kita simak buku What Went Wrong? Western Impact and Middle Eastern Response (London: Phoenix, 2002), karya Bernard Lewis, terdapat banyak data menarik tentang kondisi Islam di masa lalu dan kini. Lewis mengakui keagungan Islam di masa lalu. Ia misalnya mencatat, bahwa selama beberapa abad Islam merupakan kekuatan militer dan ekonomi terbesar di muka bumi. Tetapi, menurut Lewis,
} 
Konfrontasi: Jurnal Kultur, Ekonomi dan Perubahan Sosial, 1 (1) Januari 2014, 30-49

P-ISSN: 1410-881X (Print)

\section{Herdi Sahrasad, Perang Wacana Islam Liberal Versus Islam Fundamental}

DOI: -

http://www.konfrontasi.net/index.php/konfrontasi2

-kekuatan“ yang menakutkan, militan dan musti dikaji sekaligus diwaspadai atau diprasangkai.

Berawal dari Kongko di Kawasan Utan Kayu Kemunculan organisasi JIL berawal dari kongko-kongko antara Ulil Abshar Abdalla (Lakpesdam NU), Ahmad Sahal (Jurnal Kalam), dan Goenawan Mohamad (ISAI) di Jalan Utan Kayu 68 H, Jakarta Timur, Februari 2001. Tempat ini kemudian menjadi markas JIL. Para pemikir muda lain, seperti Lutfi Asyaukani, Ihsan Ali Fauzi, Hamid Basyaib, dan Saiful Mujani, menyu- sul bergabung. Dalam perkembangannya, Ulil disepakati sebagai koordi- nator. 13

Gelora JIL banyak diprakarsai anak muda, usia 20-35-AN tahun. Mereka umumnya para mahasiswa, kolomnis, peneliti, atau jurnalis. Tujuan utama- nya: menyebarkan gagasan Islam liberal seluas-luasnya. -Untuk itu kami memilih bentuk jaringan, bukan organisasi kemasyarakatan, maupun partai politik, $\|$ tulis situs islamlib.com, seraya mengemukakan gagasan JIL dalam Manifesto Jaringan Islam Liberal.

JIL mendaftar 28 kontributor domestik dan luar negeri sebagai -juru kam- panyell Islam liberal. Mulai Nurcholish Madjid, Djohan Effendi, Jalaluddin Rakhmat, Said Aqiel Siradj, Azyumardi Azra, Masdar F. Mas'udi, sampai Komaruddin Hidayat. Di antara kontributor mancanegaranya: Asghar Ali Engineer (India), Abdullahi Ahmed An-Na‘im (Sudan), Mohammed Arkoun (Prancis), dan Abdallah Laroui (Maroko). Jaringan ini menyediakan pentas berupa koran, radio, buku, booklet, dan website-- bagi kontributor untuk mengungkapkan pandangannya pada publik. Kegiatan pertamanya: diskusi maya (milis). Lalu sejak 25 Juni 2001, JIL mengisi rubrik Kajian Utan Kayu di Jawa Pos Minggu dan dimuat juga dalam 40-an koran jaringannya. Isi- nya artikel dan wawancara seputar perspektif Islam liberal.

Tiap Kamis sore 2001-2002, JIL menyiarkan wawancara langsung dan dis- kusi interaktif dengan para kontributornya, lewat radio $68 \mathrm{H}$ dan 15 radio jaringannya. Tema kajiannya berada dalam lingkup agama dan demokrasi. Misalnya jihad, penerapan syariat Islam, tafsir kritis, keadilan gender, jilbab, atau negara sekuler. Perspektif yang disampaikan berujung pada tesis bahwa Islam selaras dengan demokrasi.

Dalam situs islamlib.com dinyatakan, lahirnya JIL sebagai respon atas bang- kitnya -ekstremismell dan -fundamentalismell agama di Indonesia. Seperti munculnya kelompok militan Islam, perusakan gereja, lahirnya sejumlah media penyuara aspirasi -Islam militanl, serta penggunaan istilah -jihad\|l sebagai dalil kekerasan.

JIL tak hanya terang-terangan menetapkan musuh pemikirannya, juga lugas mengungkapkan ide-ide -gilall-nya. Gaya kampanyenya menggebrak, menya- lak-nyalak, dan provokatif. Akumulasi gaya ini memuncak pada artikel kon- troversial Ulil di Kompas yang dituding FUUI telah menghina lima pihak sekaligus: Allah, Nabi Muhammad, Islam, ulama, dan umat Islam. -Tulisan saya sengaja provokatif, karena saya berhadapan dengan audiens yang juga provokatif,\| kata Ulil.

Dengan gaya demikian, reaksi bermunculan. Tahun 2002 bisa dicatat seba- gai tahun paling polemis dalam perjalanan JIL. Spektrumnya beragam: mu- lai reaksi ancaman mati, somasi, teguran, sampai kritik berbentuk buku. Te-guran, misalnya, datang dari rekomendasi (taushiyah) Konferensi Wilayah Pengurus Wilayah Nahdlatul Ulama (PWNU) Jawa Timur, 11-13 Oktober 2002.

Bunyinya: -Kepada PWNU Jawa Timur agar segera menginstruksikan kepa- da warga NU mewaspadai dan mencegah pemikiran Islam Liberal dalam masyarakat. Apabila 
Konfrontasi: Jurnal Kultur, Ekonomi dan Perubahan Sosial, 1 (1) Januari 2014, 30-49

P-ISSN: 1410-881X (Print)

Herdi Sahrasad, Perang Wacana Islam Liberal Versus Islam Fundamental

DOI: -

http://www.konfrontasi.net/index.php/konfrontasi2

pemikiran Islam Liberal dimunculkan oleh Pengurus NU (di semua tingkatan) diharap ada sanksi, baik berupa teguran keras maupun sanksi organisasi (sekalipun dianulir dari kepengurusan).॥

Somasi dilancarkan Ketua Departemen Data dan Informasi Majelis Muja- hidin Indonesia, Fauzan al-Anshari, kepada RCTI dan SCTV, pada 4 Agustus 2002, karena menayangkan iklan -Islam Warna-warnill dari JIL. Iklan itupun dibatalkan. Kubu Utan Kayu membalas dengan mengadukan Fauzan ke polisi.

Di atas segalanya, aksi-reaksi yang mengiringi perjalanan JIL telah mengu- akkan kenyataan bahwa JIL mempunyai -konstituen\| tersendiri yang justru mendapat pencerahan spiritual dari Islam ala JIL ini.

Misalnya, saat berlangsung talk show radio bersama Prof. Hasanuddin A.F. tentang pidana mati dalam Islam, Desember 2002. Seorang penanya berna- ma Henri Tan mengeluh akan keluar lagi dari Islam, bila Ulil diancam- ancam fatwa mati. -Islam model Ulil ini yang membuat saya tertarik masuk Islam. Kalau model ini mau dimatikan, lebih baik saya keluar lagi dari Islam,\| katanya.

Fakta serupa muncul dalam bedah buku Syariat Islam Pandangan Muslim Liberal di Universitas Negeri Jakarta, Juni 2003. Seorang peserta, sebut saja Djohan, menyesalkan fatwa mati atas Ulil. -Saya meninggalkan Kristen dan masuk Islam justru karena keislaman model Mas Ulil. Dia bukan pendangkal akidah, malah menguatkan akidah saya,\| kata Djohan. Tuduhan bahwa JIL mendangkalkan akidah, dengan fakta ini, perlu diuji kembali.

Ketika digelar jumpa pers JIL menanggapi fatwa FUUI, di Utan Kayu, Jakar- ta, Desember 2002, ada seorang penanggap yang mengaku berislam secara -minimall, alias abangan. Tadinya ia merasa terasingkan dari wadah mayo- ritas umat Islam, tapi kehadiran JIL seolah merangkulnya, dan mengakui- nya sebagai muslim. Ia pun terdorong meningkatkan kualitas keislamannya.

\section{Tentang Istilah Islam Liberal}

Istilah Islam liberal sebenarnya merupakan istilah yang dipopulerkan oleh Charles Kurzman yang menulis buku Liberal Islam a Sourcebook. Sebe- narnya buku ini adalah kumpulan artikel. Kurzman menganggap ada sejum- lah intelektual Muslim yang merepresentasikan Islam yang liberal. Di antara intelektual Arab ada nama Ali Abdurraziq, Mahmud Toha, dan Ahmad Na'im. Buku ini terbit tahun 1998.

Sebelum buku Kurzman, ada buku lain yang juga berbicara tentang Islam liberal yaitu Islamic Liberalism yang ditulis Leonard Binder. Meskipun tidak spesifik berbicara tentang Islam Liberal, Binder memetakan aliran-aliran pemikiran yang dia kategorikan sebagai liberal. Ada buku lain yang ditulis oleh Albert Hourani, sebuah buku klasik, yaitu Arabic Thought in the Libe- ral Age. Dia merujuk masa-masa kebangkitan Arab pada awal- awal abad ke-19 atau akhir abad KE-18 sebagai masa-masa yang liberal. Jadi kalau kita melihat perkembangan tersebut dapat dilihat bahwa istilah Islam liberal tidak dimulai dari Kurzman. Istilah tersebut sudah dimulai oleh Hourani pada tahun 1900-an.

Istilah Islam Liberal mengandung konotasi negatif bagi sebagian dunia Islam dimana ia diasosiasikan dengan dominasi asing, kapitalisme tanpa batas, kemunafikan yang mendewakan kebenaran dan permusuhan kepada Islam. Namun seperti ditegaskan Charles Kurzman, Islam liberal harus dili- hat sebagai alat bantu analisis, bukan kategori yang mutlak. 
Konfrontasi: Jurnal Kultur, Ekonomi dan Perubahan Sosial, 1 (1) Januari 2014, 30-49

P-ISSN: 1410-881X (Print)

\section{Herdi Sahrasad, Perang Wacana Islam Liberal Versus Islam Fundamental}

DOI: -

http://www.konfrontasi.net/index.php/konfrontasi2

Islam liberal? -Liber\| dari bahasa Latin, artinya -bebas\|, -merdekall. Dari istilah ini kita bisa mengajukan beberapa pertanyaan sederhana: Islam (umat Islam) mau bebas dari apa? Dari kungkungan politik? Dari doktrin dan warisan-warisannya sendiri? Dari kebodohan? Selain itu, Islam (umat Islam) mau bebas untuk berbuat apa? Sekadar bebas untuk beribadah? Hidup secara demokratis dan merdeka untuk menafsirkan kembali doktrin- doktrin yang ada agar agama dan modernitas tidak bertentangan? Apa landasan konseptual yang dapat diberikan terhadap masalah -free from\| dan -free forll oleh kaum yang mengatakan diri mereka sebagai kaum Islam liberal?

Lantas, apa itu interpretasi liberal atas Islam dalam soal politik (demokrasi)? Islam liberal adalah interpretasi Islam yang mendukung atau paralel dengan civic culture (propluralisme, equal opportunity, moderasi, trust, tolerance, memiliki sense of community yang nasional). Luthfi Assyaukanie memahami -Islam Liberall sebagai Islam yang kritis, progresif, dan dinamis. -Islam Liberalll sebenarnya adalah istilah A.A. Fyzee, intelektual Muslim India, yang dipopulerkan Charles Kurzman dalam karyanya Liberal Islam).17 Istilah itu mungkin tidak terlalu penting, karena kita bisa menggantinya dengan, mi- salnya,

-Islam Progresif,\| -Islam Pluralis,\| atau -Islam Emansipatoris\| dan seterusnya. Namun Farid Esack, intelektual asal Afsel, misalnya, kurang setuju dengan penggunaan istilah -liberall karena berkonotasi perlawanan dan pemberontakan. Namun kalangan Islam Liberal di Indonesia senang menggunakannya, karena memang ada sesuatu yang harus dilawan dan ada alasan untuk memberontak. Mereka menganggap bahwa mayoritas Islam yang ada sekarang adalah Islam ortodoks, baik dalam wajahnya yang funda- mentalis (dalam sikap politik) maupun konservatif (dalam pemahaman kea- gamaan). 18 Karena itu, kata Luthfie, Islam Liberal datang sebagai sebuah bentuk protes dan perlawanan terhadap dominasi itu, untuk memecahkan persoalan yang paling mendasar, agar bebas dari otoritas masa silam dan yang diluncurkan penerbitan perdananya pada 6 Maret 2004 di Hotel Sofyan Cikini Jakarta. Format majalah dan penampilannya mengingatkan majalah Ulumul Qur'an, hanya saja Islamia sepenuhnya tampil meng-counter sekularisme, liberalisme Islam yang acap diusung -mendiang\| Ulumul Qur`an. Walau majalah Ulumul Qur_an sudah lama mati, kalangan Islam Fundamental menganggap pemikiran sekuler yang selalu diusung jurnal yang mengaku ilmiah itu justru tumbuh subur. -Tengok saja gegap-gempita penampilan kelompok Islam Liberal yang dipelopori Ulil Abshar Abdalla." Kata seorang aktivis Islam Fundamental seraya menambahkan. Perhatikan pula para pengi- kut Nurcholis Madjid melalui berbagai sarana media terus-menerus menggerus Islam yang hakiki dengan dalih pembaharuan, liberal, dan semacamnya. Kelompok mereka ini dianggap oleh Islam Fundamental, terus merajalela.

Terakhir, demikian kalangan Islam Fundamental, Paramadina menerbitkan buku Fiqih Lintas Agama yang tentu saja sangat menghebohkan. Belum lagi geger Herme- neutika yang kini diidap pula oleh sejumlah tokoh Muhammadiyah seperti Amin Abdullah dan Abdul Munir Mulkhan. Semakin banyaknya figur-figur penerus Nur- cholish Madjid yang lahir dengan aneka media yang dimiliki saat ini, rupanya sangat mengusik nurani sejumlah mahasiswa kandidat $\mathrm{Ph} . \mathrm{D}$ di Internasional Institute of Islamic Though and Civilization (ISTAC-IIUM) Kualalumpur Malaysia, khususnya yang berasal dari Indonesia, seperti Adian Huaini, Hamid Fahmy Zarkasyi (putra pendiri Pondok Modern Gontor, Alm. KH Zarkasyi), Adnin Armas, serta beberapa dosen di sana seperti Dr. Ugi Suharto (asal Indonesia) dan Prof 
Konfrontasi: Jurnal Kultur, Ekonomi dan Perubahan Sosial, 1 (1) Januari 2014, 30-49

P-ISSN: 1410-881X (Print)

Herdi Sahrasad, Perang Wacana Islam Liberal Versus Islam Fundamental

DOI: -

http://www.konfrontasi.net/index.php/konfrontasi2

Dr Wan Mohamad. Nor wan Daud, alumnus University of Chicago Amerika yang satu angkatan dengan Syafii Maarif dan Amien Rais.

Kedua, Islam Liberal hanya liberal dalam pembacaannya terhadap teks dan wacana. Tapi, maaf, tidak liberatif terhadap yang tertindas. Malah seba- liknya, cenderung menindas yang tertindas, dengan tawaran wacana yang sama sekali disconnect dengan wacana rakyat tertindas. Gus Dur itu, dalam kategori Greg Barton adalah tokoh kelas wahid Islam Liberal. Tapi, dalam gerakan politiknya, cenderung otoriter dan sama sekali tidak demokratis. Pendekatannya demokratis liberal, tapi aktualisasi gerakan politiknya cende- rung tidak demokratis. Jadi, kata Sukidi, omong kosong belaka Islam Liberal.

Ketiga, Bagaimana meletakan Islam Liberal, dalam konteks usaha liberatif? Dr. Farid Esack menentang rezim penindas apartheid di Afrika Selatan de- ngan merekontruksi teologiteologi pluralis dalam Al-Alquran untuk meng- galang -inter-faith solidarityll menentang rezim penindas. Nah, bagaimana kita meletakkan wacana Islam Liberal di Indonesia, untuk menggalang soli- daritas antar iman dalam rangka melawan rezim penindas dari tokoh Islam Liberal itu sendiri.

Haidar Bagir dan A. Gaus AF. Perbedaannya, Musthafa Bisri mencoba meng- kritisi dari metode penyampaian yang bernada -geram\| dan hanya ingin membuat geram mereka yang dalam benak bayangan Ulil dianggap sebagai biang ketidakramahan Islam di Indonesia. Saking -semangatnyall kejernihan pikiran yang seharusnya dijadikan panduan, menjadi tidak nampak. Sehing- ga alih-alih memerangi umat beragama yang terlalu -bersemangatll tanpa disertai pemahaman yang cukup atas agamanya, di mana sering merugikan agama itu sendiri, justru Ulil bersikap sama, karena semangatnya meme- rangi: \|musuh Islam\| telah mengaburkan kejernihan pikiran yang ingin disampaikan. Sementara Gaus selain mengkritik dari lemparan ide yang dianggapnya -lamall, juga sasaran kampanye. Baginya bukan saatnya lagi masyarakat, tetapi institusi atau otoritas yang membelenggu kebebasan masyarakat dalam menjalankan apa yang diyakini dari ajaran agamanya dan bukannya mengulang dari sisi wajib atau tidaknya karena itu daerah fikih ijtihadi. Dengan cara begitu apa yang menjadi obsesi Ulil cs akan terasa lebih berarti.

Sementara Haidar Bagir mempertanyakan dari sisi metodologi berpikirnya. Tulisan Ulil soal Islam Liberal, demikian Haidar Bagir, adalah kuncup-kun- cup pemikiran, sementara bagaimana kemudian kuncup itu dihasilkan ku- rang mendapat ruang pembahasan, sehingga banyak hal yang kemudian membutuhkan penjelasan secara metodologis. Haidar mencontohkan dalam masalah jilbab, jenggot, rajam dan jubah, Ulil mencampuradukkan antara isu-isu yang memperoleh dukungan petunjuk Al-Qur'an yang dianggap valid adalah hal transmisi (qath"iy wurud) dan nyaris juga valid dalam hal makna (qathi al dilalah), seperti jilbab dan potong tangan, dengan dukungan- tekstualnya bersifat kontroversial seperti memelihara jenggot, memendek- kan celana, bahkan hukum rajam (dalam Al-Qur'an masalah rajam sama sekali tidak disinggung).

\section{Berbagai Respon atas Islam Liberal (JIL)}

Jaringan Islam Liberal (JIL) merupakan kelompok atau komunitas intelek- tual Islam, yang dalam beberapa hal dinilai kalangan Islam fundamental- memiliki pemikiran yang liberal dan sekuler atau bisa juga disebut berbeda. Terutama menyangkut pemikiran keislaman yang oleh kalangan Islam tra- disional atau juga modern diyakini merupakan sesuatu yang sudah baku. Misalnya soal sekularisasi, otentisitas Al-Qur'an ada tidaknya 
Konfrontasi: Jurnal Kultur, Ekonomi dan Perubahan Sosial, 1 (1) Januari 2014, 30-49

P-ISSN: 1410-881X (Print)

Herdi Sahrasad, Perang Wacana Islam Liberal Versus Islam Fundamental

DOI: -

http://www.konfrontasi.net/index.php/konfrontasi2

syariat Islam, termasuk juga soal teologi atau ketuhanan, JIL membongkar keyakinan yang telah diyakini selama ini oleh kaum Muslim pada umumnya dengan pemi- kiran pemikiran yang liberal.20

Adnin Armas (Pengaruh Kristen Orientalis terhadap Islam Liberal, 2004) dari Islam Fundamental melihat, JIL terlalu lepas kendali. JIL dinilainya telah terpengaruh oleh pemikiran kaum Kristen dan orang orientalis yang memang telah lama mendorong sekularisasi. Bagaimanapun sekularisasi merupakan gagasan yang sentral bagi kelompok Islam Liberal yang diko- mandoi oleh Ulil Abshor Abdalla. Di mata Armas, pemikiran yang dikem- bangkan kelompok JIL ini memang telah lama dikembangkan oleh orang orientalis Barat dan misionaris Kristen yang kemudian kini dilakukan dalam proses sekularisasi dan liberalisasi Islam. Pembongkaran akar-akar ajaran Islam seperti dekonstruksi Al-Qur'an dan tafsirnya merupakan pemikiran yang telah memasuki wilayah sensitif dalam keyakinan Islam. Dan JIL mela- kukan hal itu.

\section{Soal Syariat Islam}

Aktivis Islam Liberal Luthfi Assyaukanie meyakini tak ada Syariat Islam. Ia menganggap bahwa konsep Syariat Islam tidak ada. Itu, ungkapnya, adalah karangan orang- orang yang datang belakangan yang memiliki idealisasi yang berlebihan terhadap Islam (sama seperti negara Islam, ekonomi Islam, Bank Islam, dan lain-lain). Menurutnya, semua hukum yang diterapkan dalam masyarakat pada dasarnya adalah hukum positif. Termasuk hukum yang dibelakukan oleh Nabi. Kalaupun sumber konstitusinya berasal dari Al Qur'an, tambah luthfi, hal ini karena Muhammad adalah seorang Rasul. Dan beliau tidak memiliki konstitusi yang lebih baik, yang available pada saat itu selain Al Qur'an. Pada banyak kasus, delik-delik perundangan yang diterap- kan Muhammad dan kawan kawannya malah mengambil semangat hukum adat (urf), termasuk dalam kasus rajam, potong anggota badan secara silang, pembakaran manusia (dalam kasus sodomi) dan denda (diyat, yang diambil dari kodifikasi Romawi dan Nabatean). Hanya sedikit yang beliau ambil dari Al Qur'an.

Armas menanggapi pendapat Luthfi dengan mengatakan, kalaupun ada sedi- kit persamaan, hal itu tidak berarti tidak adanya nilai fundamental dan nilai yang mendasar. Memang Rasulullah SAW juga membawa risalah yang per- nah disampaikan nabi-nabi sebelumnya, sehingga muncul kemiripan. Tetapi tidak sama sekali menafikan perbedaan yang sangat mendasar. Oleh karena itu, Islam (konsep syahadah dan syariatnya) adalah agama yang baru sama sekali. Bukan tiruan yang diubah sesuaikan. Di sini Armas ingat usaha orien- talis yang ingin mensosialisasikan ide seperti pengaruh Yahudi dan Kristen sedemikian besar sehingga Islam tidak bisa dianggap superioritas dari aga- ma lain.

Ulil Abshar Abdalla sendiri optimis bahwa Islam yang diusungnya akan ber- kibar di masa depan. -Saya semakin optimis, bahwa Islam liberal ini akan menjadi maazhab ke depan yang segera akan menggantikan madzhab Hana- fi, Maliki, Syafi'i, Hambali, Ja'fary dan yang lain, “" kata Ulil.

Selain dua kelompok di atas, ada lagi para aktivis-intelektual (terutama maz- hab Jogya dengan LKiS sebagai -sponsor utamall dan dalam hal tertentu keislaman yang dikembangkan The (Abdurrahman Wahid Institute) yang mengkritik JIL karena dipandang terlalu -ke-BaratBarat-an,\| corong mo- dernisme, mengembangkan wawasan sekularisme, kapitalisme global 
Konfrontasi: Jurnal Kultur, Ekonomi dan Perubahan Sosial, 1 (1) Januari 2014, 30-49

P-ISSN: 1410-881X (Print)

Herdi Sahrasad, Perang Wacana Islam Liberal Versus Islam Fundamental

DOI: -

http://www.konfrontasi.net/index.php/konfrontasi2

dan lain-lain. Menurut para aktivis Islam di Wahid Institute, wajah Islam yang mestinya ditampilkan adalah -Islam Kirill sebagai kritik atas hegemoni kebu- dayaan Barat yang mencengkeram di hampir semua kawasan Islam bukan malah -berlindungll di balik jubah modernisme Barat. Masih banyak lagi kritikan yang dialamatkan ke JIL.

Islam Liberal yang ditulis Hartono Ahmad Jaiz, mantan wartawan, Pengaruh KristenOrientalis terhadap Islam Liberal (karya Adnin Armas). Juga Islam Liberal: Sejarah, Konsepsi, Penyimpangan dan Jawabannya (buku karya Adian Husaini) dan lain-lain. Ini belum termasuk berbagai tulisan di media massa.

\section{Respon Islam Fundamental atas Islam Liberal}

Lebih jauh lagi, kalangan Islam Fundamental melihat, firqah halikah adalah firqah Liberaliyah. Liberaliyah adalah sebuah paham yang berkembang di Barat dan memiliki asumsi, teori dan pandangan hidup yang berbeda, yang keluar atau menyimpang darinya sehingga termasuk firqah-firqah yang halikah (kelompok yang binasa).

Dalam tesisnya yang berjudul -Pemikiran Politik Baratl Ahmad Suhelmi, MA PhD menjelaskan prinsip-prinsip pemikiran ini.24 Pertama, prinsip ke- bebasan individual. Kedua, prinsip kontrak sosial. Ketiga, prinsip masya- rakat pasar bebas. Keempat, meyakini eksistansi Pluralitas Sosio - Kultural dan Politik Masyarakat.

Menurut para aktivis Islam fundamental, Islam dan Liberal adalah dua isti- lah yang antagonis, saling berhadap-hadapan tidak mungkin bisa bertemu. Namun demikian ada sekelompok orang di Indonesia yang rela menamakan dirinya dengan Jaringan Islam Liberal (JIL). Suatu penamaan yang -pasll dengan orang-orangnya atau pikiran-pikiran dan agendanya. Islam adalah pengakuan bahwa apa yang mereka suarakan adalah haqq tetapi pada haki- katnya suara mereka itu adalab bathil karena liberal tidak sesuai dengan Islam yang diwahyukan dan yang disampaikan oleh Rasul Muhammad, akan tetapi yang mereka suarakan adalah bid'ah yang ditawarkan oleh orang- orang yang ingkar kepada Muhammad Rasulullah.

Kalangan Islam Fundamental menyikapi Islam Liberal melalui tatapan me- reka atas visi, misi agenda dan bahaya mereka, seperti terurai di bawah ini.

\section{Sanad (asal-usul) Firqah Liberal}

Islam liberal menurut Charless Kurzman muncul sekitar abad ke-18 di kala kerajaan Turki Utsmani Dinasti Shafawi dan Dinasti Mughal tengah berada di gerbang keruntuhan. Pada saat itu tampillah para ulama untuk menga- dakan gerakan permurnian, kembali kepada Al-Qur'an dan sunnah. Pada saat ini muncullah cikal bakal paham liberal awal melalui Syah Waliyullah (India, 1703-1762), menurutnya Islam harus mengikuti adat lokal suatu tem- pat sesuai dengan kebutuhan pcnduduknya. Hal ini juga terjadi di kalangan Syi'ah. Ada Muhammad Bihbihani (Iran, 1790) mulai berani mendobrak pintu ijtihad dan membukanya lebar-lebar.

Ide ini terus bergulir. Rifa'ah Rafi‘ al-Tahtawi (Mesir, 1801-1873) mema- sukkan unsurunsur Eropa dalam pendidikan Islam. Shihabuddin Marjani (Rusia, 1818-1889) dan Ahmad Makhdun (Bukhara, 1827-1897) mema- sukkan mata pelajaran sekuler ke dalam kurikulum pendidikan Islam (Char- less Kurzman: xx-xxiii)

Di India muncul Sir Sayyid Ahmad Khan (1817) yang membujuk kaum mus- limin agar mengambil kebijakan bekerja sama dengan penjajah Inggris. Pada tahun 1877 ia membuka 
Konfrontasi: Jurnal Kultur, Ekonomi dan Perubahan Sosial, 1 (1) Januari 2014, 30-49

P-ISSN: 1410-881X (Print)

Herdi Sahrasad, Perang Wacana Islam Liberal Versus Islam Fundamental

DOI: -

http://www.konfrontasi.net/index.php/konfrontasi2

suatu kolese yang kemudian menjadi Universitas Aligarh (1920). Sementara Amir Ali (18791928) melalui buku The Spirit of Islam berusaha mewujudkan seluruh nilai liberal yang dipuja di Inggris pada masa Ratu Victoria. Amir Ali memandang bahwa Nabi Muhammad adalah Pelopor Agung Rasionalisme. (William Montgomery Waft: 132).

Al-Qur'an adalah sebuah kebenaran. Sehingga alih-alih mengikuti pandang- an kaum konservatif Kristen yang menganggap bahwa Al-Qur'an adalah replikasi dari kitab-kitab suci umat terdahulu, Watt justru membangun mazhabnya sendiri dengan mengatakan bahwa Alquran adalah benar dari Tuhan dan ia merepresentasikan orisinalitasnya sendiri. Untuk membukti- kan pandangannya, Watt menampilkan bukti bahwa pada ayat-ayat Ma- kiyyah, selalu terdapat poin-poin berikut ini: 1) bahwa Tuhan adalah Maha Kuasa dan Pengasih; 2) bahwa manusia akan menghadap Tuhan pada hari akhir nanti untuk mendapatkan pengadilan atas perbuatannya; 3) Manusia harus tunduk pada Tuhan dan menyembah-Nya;

4) manusia harus mau mengeluarkan zakat dan menjalankan kebenaran, serta 5) Muhammad telah diutus oleh Allah. Adalah benar semata, kata Watt, bahwa empat poin di atas juga telah disebutkan dalam Bibel, tetapi poin terakhir yang menyatakan bahwa Muhammad adalah utusan Allah, menunjukkan bahwa Al-Qur'an memiliki orisinalitas yang terpisah dari wahyu yang terdapat dalam agama Yahudi maupun Kristen.29 Tak kurang dari Watt, Hans Kung juga menyatakan bahwa Al-Qur'an telah menyediakan umat Islam dengan pemi- kiran tentang kewajiban moral, dinamika eksternal dan kedalaman reli- giusnya. Kenyataan ini terjadi, karena umat Islam meyakini Al-Qur'an seba- gai kitab suci, dan lebih dari itu mereka memahaminya bukan sebagai per- kataan manusia, melainkan perkataan Tuhan yang suci.

Misi Firqah Liberal

Dalam persepsi Islam garis keras, misi Firqah Liberal adalah untuk meng- hadang (tepatnya: menghancurkan) gerakan Islam Fundamental (www. islamlib.com). Mereka menulis: -sudah tentu, jika tidak ada upaya-upaya untuk mencegah dominannya pandangan keagamaan yang militan itu, boleh jadi, dalam waktu yang panjang, pandangan-pandangan kelompok keagamaan yang militan ini bisa menjadi dominan. Hal ini jika benar terjadi, akan mempunyai akibat buruk buat usaha memantapkan demokratisasi di Indo- nesia. Sebab pandangan keagamaan yang militan biasanya menimbulkan ketegangan antar kelompok- kelompok agama yang ada. Sebut saja antara Islam dan Kristen. Pandangan-pandangan keagamaan yang terbuka (inklu- sif) plural, dan humanis adalah salah satu nilai-nilai pokok yang mendasari suatu kehidupan yang demokratis.\|

\section{Agenda dan Gagasan Firqah Liberal}

Kalangan Islam fundamental melihat dalam tulisan berjudul -Empat Agenda Islam Yang Membebaskanll yang ditulis oleh Luthfie Asyaukanie salah seo- rang penggagas JIL yang juga peneliti Freedom Institute31 memperkenalkan empat agenda Islam Liberal.

Pertama, agenda politik. Menurutnya urusan negara adalah murni urusan dunia, sistem kerajaan dan parlementer (demokrasi) sama saja. Kedua, mengangkat kehidupan antara agama. Menurutnya perlu pencarian teologi pluralisme mengingat semakin majemuknya kehidupan bermasyarakat di negeri-negeri Islam. Ketiga, emansipasi wanita dan, Keempat, kebebasan berpendapat (secara mutlak).

Sementara dari sumber lain kita dapatkan empat agenda mereka32 adalah:

1.Pentingnya konstekstualisasi ijtihad 
Konfrontasi: Jurnal Kultur, Ekonomi dan Perubahan Sosial, 1 (1) Januari 2014, 30-49

P-ISSN: 1410-881X (Print)

\section{Herdi Sahrasad, Perang Wacana Islam Liberal Versus Islam Fundamental}

DOI: -

http://www.konfrontasi.net/index.php/konfrontasi2

2. Komitmen terhadap rasionalitas dan pembaruan

3. Penerimaan terhadap pluralisme sosial dan pluralisme agama-agama

Dihadapkan kepada kompleksitas di atas, kalangan Islam Fundamental te- tap tegas menolak gagasan Islam Liberal, termasuk soal pluralisme. Dalam persepsi mereka, pluralisme ini memang sesuatu faham yang bertentangan dengan Islam bukan hanya karena disebutkan di dalam Al-Qur'an surat Al- Baqarah ayat 120 dan yang lainnya, tapi juga karena pluralisme itu, menurut Islam Fundamental, intinya teologi yang dibagi menjadi tiga: 34

- Ada teologi eksklusif, yaitu orang yang hanya memandang agamanya saja yang benar, di luar agamanya salah, tidak ada kebenaran tidak ada kese- lamatan.

- Kemudian meningkat lagi teologi inklusif yaitu orang yang berpandangan agamanya benar agama orang lain juga benar, ada kebenaran tetapi aga- manya masih lebih benar sehingga dia masih mengikuti agamanya. Ini inklusif tetapi sudah terbuka wawasannya.

- Lalu teologi pluralis yang tertinggi, memandang bahwasanya kebenaran itu di manamana agamanya benar dan agama yang lain juga benar dan dia ikut aktif terlibat di dalam aktifitas agama orang lain juga. Itu benar- benar pluralis sejati.

Kalangan fundamental menuding barisan liberal membuat barisan-barisan khusus untuk misi meliberalisasi dan menyebarkan pahamnya, sementara yang zionis menyebarkan paham zionisnya. Bukan menarik orangnya ke da- lam zionis tetapi bagaimana orang berkhidmat kepada zionisnya dan tun- duk patuh kepada zionisnya.

Dalam soal terorisme yang dewasa ini banyak menyudutkan citra Islam, ka- langan JIL memiliki pandangan paralel dengan AS/Barat dalam melihat Islam Fundamental yang sering dikaitkan dengan terorisme itu. Tindakan -anarkismell dengan gerakan Islam memiliki ciri-ciri khusus sebagaimana ditulis oleh mantan Presiden AS Ricard Nixon dalam Seize The Moment yang dikutip oleh Muhammad Imarah dalam Fundamentalisme dalam Perspektif Pemikiran Barat dan Islam (1999:35), bahwa -Islam Funda- mentall adalah mereka yang mempunyai ciri gerakan: 1) Anti peradaban Barat,

2) Ingin menerapkan syariat Islam, 3) Akan membangun peradaban Islam, 4) Tidak memisahkan antara Islam dan negara, dan 5) Menjadikan para pendahulu (salaf) sebagai panduan masa depan (khalaf). Kelima ciri inilah yang dijadi-kan tolok ukur untuk menilai apakah gerakan Islam itu pantas disebut -fundamentalis\| atau tidak.

Kritik atas Islam Liberal Berirama Ancaman Mati

-Pada akhir zaman, akan muncul sekelompok anak muda usia yang bodoh akalnya. Mereka berkata menggunakan firman Allah, padahal mereka telah keluar dari Islam, bagai keluarnya anak panah dari busurnya. Iman mereka tak melewati tenggorokan. Di mana pun kalian jumpai mereka, bunuhlah mereka. Orang yang membunuh mereka akan mendapat pahala di hari kiamat.\|

Motto itu bukan sembarang untaian kata. Melainkan terjemahan hadis Nabi Muhammad SAW, yang tersimpan dalam kitab Al-Jami' al-Shahih karya Imam Bukhari. Mayoritas kaum muslim menilai hadis hasil seleksi Bukhari memiliki kadar kesahihan amat tinggi. Jadi, perintah membunuh dalam hadis itu bisa dipahami sebagai kewajiban syar'i (bemuatan agama) yang bernilai ibadah.

Buku itu terbit Januari 2002, bersamaan dengan maraknya pemberitaan tentang komunitas anak muda yang menamakan diri Jaringan Islam Liberal (JIL). Penempatan hadis riwayat Ali bin Abi Thalib tersebut sebagai motto buku mengundang pertanyaan: apakah 
Konfrontasi: Jurnal Kultur, Ekonomi dan Perubahan Sosial, 1 (1) Januari 2014, 30-49

P-ISSN: 1410-881X (Print)

\section{Herdi Sahrasad, Perang Wacana Islam Liberal Versus Islam Fundamental}

DOI: -

http://www.konfrontasi.net/index.php/konfrontasi2

Islam liberal yang dikupas buku itu, sudah masuk kriteria kelompok yang dimaksud isi hadis, sehingga wajib dibunuh?

Sang penulis tak menjawab ya atau tidak. -Itu harus diputuskan lewat meka- nisme hukum,\| ujar Hartono. Hadis tersebut, kata alumnus IAIN Yogyakarta ini, bersifat umum. Karena itu, Hartono menyadari, penerapannya bisa me- nimbulkan fitnah dan perselisihan. Maka perlu pelibatan aparat hukum un- tuk meredam sengketa. Sesuai dengan kaidah fikih: hukmu al-hakim yarfa'u al-khilaf (putusan pihak berwenang berfungsi menyudahi polemik).

Pada akhir buku, Hartono menyerukan pengadilan atas Islam Liberal yang ia nilai -jauh dari kebenaranll. Namun, secara tersirat, ia tetap menyarankan sanksi bunuh, ketika menutup buku dengan menampilkan kisah Umar bin Khattab yang membunuh orang yang menolak berhukum dengan syariat Islam. Di antara dosa JIL, di mata Hartono, juga menolak syariat Islam.

Ibn Hajar al-Asqalani, dalam bukunya, Fathul Bari --sebuah elaborasi (sya- rah) atas Shahih Bukhari-- menjelaskan, hadis tersebut diwartakan Ali keti- ka hendak menumpas pembangkangan kaum Khawarij (Haruriyah). Yakni kelompok yang sangat literal memahami Al-Qur'an dan menilai Ali telah kafir.

Khawarij dikenal mudah mengafirkan sesama muslim, dan tak segan mem- bunuh muslim yang mereka vonis kafir. Komunitas jenis inilah yang dimak- sud hadis tersebut saat itu. Pada awal 2002, Hartono memakai hadis itu untuk buku tentang komunitas liberal, bukan kelompok literal sejenis Kha- warij.

Dengan demikian, berita gempar fatwa mati yang pernah menimpa JIL pada akhir 2002 telah mendapat pengantar -akademik\| dari buku Hartono, 11 bulan sebelumnya. Bila di awal 2002 Hartono mewacanakan eksekusi bunuh terhadap Islam liberal, menjelang akhir tahun, lontaran itu mengkristal dalam bentuk -fatwa matill.

Sejumlah agamawan yang tergabung dalam Forum Ulama Umat Indonesia (FUUI), pada 30 November 2002, berkumpul di Masjid Al-Fajar, Bandung, dan mengeluarkan pernyataan berisi fatwa itu. Pernyataan FUUI berbunyi, -Menuntut aparat penegak hukum untuk membongkar jaringan dan kegiat- an yang secara sistematis dan masif melakukan penghinaan terhadap Allah, Rasulullah, umat Islam, dan para ulama.\|

Mereka terpicu tulisan provokatif Ulil Abshar Abdalla, Koordinator JIL, di Kompas, 18 November 2002, berjudul -Menyegarkan Kembali Pemahaman Islam\|, yang dirujuk sebagai contoh penghinaan agama. FUUI menyatakan, -Menurut syariat Islam, oknum yang menghina dan memutarbalikkan kebe- naran agama dapat diancam dengan hukuman mati.l

Menurut Ketua FUUI, KH Athian Ali, fatwanya tak hanya untuk Ulil. -Ter- lalu kecil jika kami hanya menyorot Ulil. Kami ingin membongkar motif di balik Jaringan Islam Liberal yang dia pimpin, „ kata Athian. Sepanjang tahun 2002, karena itu, menjadi tahun seruan kematian atas JIL.

Fatwa itu menyulut kontroversi luas. Sikap FUUI menuai banyak kecaman. Inti kecaman itu: berbeda pendapat boleh, tapi jangan menebar maut. $\mathrm{Cu}$ - kuplah sejarah memberi pelajaran pahit: dari Al-Hallaj (Baghdad), Siti Jenar (Demak), Hamzah Fansuri (Aceh), Farag Faudah ( Mesir), sampai Mahmoud Taha (Sudan) yang kehilangan nyawa karena pikiran berbeda.

Akhirnya FUUI mengklarifikasi: mereka tak mengeluarkan -fatwa matill. -Kami hanya menuntut proses hukum, $\|$ kata Athian. Ia membuktikan uca- pannya dengan mengadukan Ulil ke Mabes Polri, sepekan kemudian. FUUI memang tak menyebut kata 
Konfrontasi: Jurnal Kultur, Ekonomi dan Perubahan Sosial, 1 (1) Januari 2014, 30-49

P-ISSN: 1410-881X (Print)

Herdi Sahrasad, Perang Wacana Islam Liberal Versus Islam Fundamental

DOI: -

http://www.konfrontasi.net/index.php/konfrontasi2

-fatwa matill, tapi Athian menyatakan, dasar hukum sikapnya terhadap JIL sama dengan sikap kepada Pendeta Suradi. Pada Februari 2001, FUUI terang-terangan memakai kata -fatwa matill untuk Suradi.

\section{Agama dan Tafsir}

Tatkala agama mengalami proses pelembagaan (institusionalisasi) yang ber- lebihan, maka yang tejadi adalah pembungkaman kekayaan tafsir Kitab Suci. Di luar tafsir resmi yang diakui oleh lembaga berwenang, mustahil ada tafsir lain yang diakui kebenarannya. Kitab Suci yang semula terbuka kepada se- mua tafsir, dibungkam suaranya menjadi hanya -berbunyi satu tafsir\| saja (monophonic exegesis). Masyarakat agama-agama yang berada di luar dae- rah tafsir -resmill itu, akan dicap murtad atau berbuat bid'ah. Jika sudah demikian, maka lahirlah karikatur-karikatur sejarah semacam lembaga in- kuisisi pada masa Al- Makmun (untuk kasus Islam) atau pada masa Refor- masi (untuk kasus Kristen). Bahkan, ironisnya, karikatur itu masih dapat kita saksikan pada masa kini di Indonesia, misalnya --untuk menyebut con- toh yang paling mutakhir- polemik -panas\| sekitar pembaharuan Islam yang dilancarkan Nurcholish Madjid.

Keseluruhannya itu menunjukkan bahwa ketika agama telah menjadi sebuah lembaga yang dimonopoli oleh otoritas tertentu, maka dia akan kehilangan wataknya sebagai agama.

-pembebas\|, tetapi sebaliknya, sebagai hakim yang membagi-bagikan vonis kepada umatnya yang berbuat bid'ah atau penye- lewengan tafsir.

Tapi, anehnya, fenomena pelembagaan ini (institutionalizing religion phe- nomenon), terjadi pada semua agama di dunia. Jika selama ini kita me- nyaksikan adanya perang, atau setidaknya konflik panas, antar-agama, maka sebenarnya, yang bekerja di situ, untuk sebagian besar, adalah kepentingan -lembagall agama yang mempertahankan interesnya masingmasing, bukan nurani umat yang acapkali lebih mampu membaca -kebenaran\| sebagai sesuatu yang -beyond the religion as institutionll; sesuatu yang melebihi agama sekedar sebagai lembaga; agama sebagai representasi dari kebenaran yang terhunjam dalam -bumi nurani terbersih\| dari manusia yang sejak kelahirannya membawa fitrah kebenaran sebagaimana pernah ditunjukkan agama-agama (dalam Islam, misalnya, terdapat sebuah hadits: istafti qalba- ka mintalah petunjuk pada hatimu).

Tantangan semua umat beragama saat ini adalah terletak pada kenyataan bahwa semua agama telah -disapu habis\| oleh badai proses pelembagaan yang telah mematikan pesan-pesan profetisnya yang membebaskan selama ini. Bagaimana umat beragama sekarang, menghadapi perubahan cepat pada level kosmis, melakukan tafsir ulang atas teks agamanya masing- masing? Ini menjadi niscaya, jika agama-agama itu tidak ingin ditinggalkan oleh umat-nya atau dikubur oleh proses sejarah yang bergerak cepat saat ini.

\section{Metode Dekonstruksi}

Dalam ilmu humaniora saat ini, metode -dekonstruksill yang diperkenalkan oleh Jacques Derrida, - salah seorang filsuf pos-strukturalis terkemuka saat ini,-- telah populer sebagai acuan. Metode ini memberikan sumbangan yang cukup penting, terutama dalam bidang kritik sastra. Metode ini, kemudian, dipinjam oleh berbagai disiplin humaniora. Bahkan seorang pemikir Islam avant-gardis kelahiran Aljazair yang sekarang tinggal di Perancis, Mohamad Arkoun, telah menggunakan metode itu untuk melakukan rekonstruksi kembali tradisi keilmuan klasik Islam. 
Konfrontasi: Jurnal Kultur, Ekonomi dan Perubahan Sosial, 1 (1) Januari 2014, 30-49

P-ISSN: 1410-881X (Print)

Herdi Sahrasad, Perang Wacana Islam Liberal Versus Islam Fundamental

DOI: -

http://www.konfrontasi.net/index.php/konfrontasi2

Jika metode dekonstruksi diterapkan ke dalam teks-teks agama dan ideologi, maka pertama-tema yang mesti dilakukan adalah -memisahkan\| hubungan- monolinier antara teks dengan -maknall-[baca : tafsir]-nya. Keyakinan, bah- wa ada hubungan yang -final' antara suatu teks dengan tafsir tertentu, mesti dibongkar. Sebab, keyakinan semacam itu, akan menimbulkan berbagai dampak negatif. Pertama, fanatisme terhadap tafsir tertentu, serta menolak kemungkinan keabsahan tafsir yang lain. Kedua, akan menutup kemung- kinan terbukanya teks terhadap berbagai penafsiran. Dengan tertutupnya keragaman tafsir itu, maka sebuah teks akan mengalami semacam pem- busukan. Ketiga, suatu teks yang telah dibungkam melalui peresmian satu tafsir saja, akan menyebabkan teks itu tak bermakna lagi dalam menghadapi derasnya perubahan sosial pada zaman modern dewasa ini. Dekonstruksi terhadap teks, berarti membuka kemungkinan terhadap keragaman tafsir atas suatu teks. Sebab, hubungan yang linier dan final antara teks dengan tafsirnya telah putus.

Keragaman itu sendiri merupakan dasar dari kenyataan bahwa -kebenaran\| toh juga bukan tunggal. Pemahaman mengenai kebenaran tunggal itu, sebe- narnya berkaitan dengan asumsi akan adanya -Sang Aku-Transenden\| yang tahu segala-galanya mengenai teks, sehingga tafsir yang diproduksinya mempunyai -kewenangan tunggal\| atas daerah kebenaran. Maka, ketika -Sang Aku-Transenden\| itu didekonstruksi lewat konsep mengenai, —untuk meminjam istilah Mohamad Arkoun,_- -historisitas logos\| dan, dengan demikian, juga berarti -historisitas tafsir\|, maka kewenangan tunggal itu kehilangan -daya dukung\|nya. Di situlah muncul alternatif -pluralitas taf- sirll. Dalam konteks pluralisme itulah, hegemoni tafsir diruntuhkan, dan teks menjadi -hidup\| kembali serta terbuka atas semua tafsir. Dengan runtuhnya -hegemonill tersebut, runtuh pula -feodalisme teks\| pada agama yang menja- di awal mula dari kebekuan pemikiran selama ini.

Kekhawatiran atas Pertarungan Diskursus antara Islam Funda- mental dan Islam Liberal

Tulisan Ulil Abshar Abdalla -Menyegarkan Kembali Pemahaman Islam Kitall yang dimuat Kompas (18 November 2002) dan kemudian dibukukan dalam Islam Liberal dan Fundamental: Sebuah Pertarungan Wacana, memang menarik untuk diperdebatkan, meski mungkin memunculkan militansi da- lam beragama. Munculnya tudingan sesat, kafir, bahkan darahnya dihalal- kan adalah contoh, betapa telah terjadi perdebatan tidak sehat dalam mengkonstruksi pemikiran keagamaan.44 Situasi demikian, apabila tidak disikapi secara hati-hati, hanya akan menjebak dan menyeret kita pada sikap fana- tisme buta yang kemudian memunculkan primordialisme atas nama agama.

Untuk itu, perlu dikedepankan _barometer' yang dapat dijadikan pijakan dan ukuran dalam bertindak.

Dalam pertarungan wacana sebagai respon atas Islam Liberal, maka kaum aktivis fundamental juga mengemukakan gagasan dan pemikirannya yang mendasar. Setidaknya ada semacam kekhawatiran yang disertai kecurigaan dari keduanya (Islam fundamental dan Islam liberal) mengenai masa depan Islam di Indonesia.

Pertama, Islam fundamental khawatir jika ajaran Islam yang begitu luhur itu pada akhirnya nanti harus tercerabut dari akarnya akibat kampanye yang dilakukan oleh Islam liberal untuk membentuk masyarakat tanpa teks.

Kedua, sementara Islam liberal juga khawatir jika ajaran Islam itu hanya dimaknai secara tekstual/skriptural, sedangkan persoalan dunia yang kian hari semakin kompleks 
Konfrontasi: Jurnal Kultur, Ekonomi dan Perubahan Sosial, 1 (1) Januari 2014, 30-49

P-ISSN: 1410-881X (Print)

\section{Herdi Sahrasad, Perang Wacana Islam Liberal Versus Islam Fundamental}

DOI: -

http://www.konfrontasi.net/index.php/konfrontasi2

menuntut pemaknaan ajaran agama secara kon- tekstual. Ada banyak persoalan yang secara letterlijk tidak ada dalam teks agama, dan itu berarti menuntut para pemeluk agama untuk memaknainya secara kontekstual, yang disesuaikan dengan perkembangan zaman.

Perbedaan sudut pandang dan prinsip itu ini sangat berarti karena mun- culnya perdebatan yang saling berhadapan tersebut, jika dikaji secara men- dalam, sejatinya bukan ditujukan untuk membangun dan membentuk para- digma berpikir positif demi terwujudnya tatanan masyarakat yang santun dan berkeadaban (civilized), tetapi lebih sebagai _perebutan otoritas' ${ }^{6}$ wacana keagamaan. Yakni, perebutan posisi penafsiran agama sebagai wilayah _sak- ral' yang tidak semua orang boleh menyentuhnya. Penafsiran atas doktrin agama hanya boleh dilakukan oleh mereka yang telah mendapatkan kriteria- kriteria tertentu, bukan oleh semua pemeluk agama.

Di sinilah pandangan Muhtadin AR, mengutip pemikiran Ritzer dalam A Multiple Paradigm Science (1975), tentang =wacana' menarik untuk dikede- pankan. Menurutnya, wacana dalam teori sosial, sangat bersifat politik. Ia bukan lagi menjadi persoalan benar atau salah, tetapi telah menjelma menjadi persoalan menang atau kalah. Kemenangan suatu teori terhadap teori lainnya, menurutnya, lebih disebabkan karena para pendukung dari teori yang menang itu lebih memiliki kekuatan dan kekuasaan dari pengikut teori yang dikalahkan. Dan sekali lagi, bukan karena teori tersebut lebih benar atau lebih baik dari yang dikalahkan.46

Kalau kita berpijak pada ungkapan Ritzer di atas, maka sangat wajar apabila perdebatan seputar pemikiran keagamaan bisa berakhir di meja kepolisian,kekuasaan.

Menghadapi situasi yang kurang harmonis ini, kajian sosiologis terhadap masyarakat sebenarnya akan menemukan relevansinya. Pertama, otoritas pemahaman keagamaan sampai saat ini masih dimonopoli orang dan ke- lompok tertentu. Setiap pemeluk agama belum sepenuhnya diberikan hak dalam menentukan pilihan atas otoritas pemahaman keagamaannya. Akibat- nya, masing-masing kelompok otoritas ini memberikan definisi terhadap la- wan, disesuaikan dengan kepentingan kelompoknya, dan tidak sedikit yang bernada _provokatif'.

Pemberian label lawan yang ditetapkan Islam Fundamantal dan Islam Libe- ral misalnya, sangat jelas sekali menunjukkan antagonisme itu. Islam Fun- damental mendefinisikan bahwa lawan' yang harus disingkirkan adalah orang dan kelompok yang tidak mau berpegang pada teks keagamaan, dan itu adalah Islam liberal. Sementara Islam Liberal mendefinisikan bahwa orang atau kelompok yang harus disingkirkan adalah mereka yang sangat berpegang teguh pada teks, tanpa melakukan pemaknaan ulang terhadap konteks yang terjadi di sekelilingnya, dan itu adalah Islam Fundamental.

Kedua, sampai saat ini, kajian terhadap pemahaman keagamaan masih me- nempatkan masyarakat sebagai _objek' ketimbang _subjek'. Otoritas pema- haman keagamaan belum menjadi hak setiap pemeluk agama, tetapi masih menjadi milik para _penguasa' agama. Masyarakat yang sejatinya juga peme- luk agama belum sepenuhnya diberi kebebasan untuk menentukan pilihan atas otoritas pemahaman keagamaannya sendiri.

Hal demikian terlihat dari munculnya counter wacana _kurang sehat' dari masing- masing orang dan kelompok yang secara ideologi maupun meto- dologi pemahaman keagamaan, sangat berbeda. Masing-masing penguasa agama belum sepenuhnya rela' jika kelompok lain melemparkan wacana yang menurut (kelompok)-nya dianggap salah dan membahayakan.

Ada kesan bahwa ="pertikaian" paradigma berpikir semacam ini tidak disi- kapi secara arif, sehingga apabila dibiarkan terus berkembang, tidak akan menyelesaikan masalah, bahkan 
Konfrontasi: Jurnal Kultur, Ekonomi dan Perubahan Sosial, 1 (1) Januari 2014, 30-49

P-ISSN: 1410-881X (Print)

\section{Herdi Sahrasad, Perang Wacana Islam Liberal Versus Islam Fundamental}

DOI: -

http://www.konfrontasi.net/index.php/konfrontasi2

cenderung memperuncing masalah, karena kedua kelompok yang berseberangan tersebut (Islam Liberal dan Islam Fundamental) selamanya akan selalu berhadapan. Dan dihadapan kedua pihak, ada kawasan kosong yang bisa menimbulkan berbagai kemungkinan di mana sangat mungkin masing-masing akan memunculkan jurus baru untuk mementahkan argumen lawannya, begitu seterusnya.

Para aktivis Muslim melihat kenyataan demikian sebagai peringatan keras yang menuntut kalangan Islam yang peduli agar bersikap arif, waspada, sa- bar dan hati-hati. Karena jika tidak, ke depan kita tidak hanya akan disuguhi pemandangan munculnya sebuah tatanan masyarakat yang terkotak-kotak dalam gerakan dan pemahaman keagamaan, sebuah masyarakat yang terpolarisasi dalam sekat keagamaan yang sangat sempit dan tidak membebaskan, tetapi juga munculnya masyarakat dengan paradigma berpikir tidak toleran, yang tidak bisa menerima keberbedaan.

Pada aras demikian, mempertemukan antara Islam Fundamental dan Islam Liberal merupakan suatu keharusan.

Bertemu bukan sekadar mendialogkan gagasan, tetapi menawarkan gagasan itu kepada publik (masyarakat) secara sehat tanpa disertai pretensi apa pun terhadap kelompok lain. Artinya, sampai seberapa jauh kedua gagasan ter- sebut memiliki concern dan pemihakan terhadap persoalan-persoalan ma- syarakat? Dengan posisi seperti itu, masyarakat tidak lagi akan menjadi objek dari pemahaman keagamaan, tetapi berubah menjadi subjek bagi pi- lihan yang akan ditentukannya, termasuk ketika mereka tidak menentukan pilihan. Kecenderungan ke mana masyarakat akan membutuhkan konsep dan gagasan yang ditawarkan keduanya, dapat dilihat dari respons, simpati, dan kebutuhan masyarakat.

Adakah Jalan Tengah?

Para pengamat Islam melihat persoalan _wacana' Islam Liberal dan Funda- mental pada akhirnya adalah persoalan politis, yang tidak lagi bertutur ten- tang benar atau salah, tetapi sudah bergeser menjadi persoalan menang dan kalah. Dan, inilah tantangan terbesar kita. Untuk itu, "keganasan"، Islam Fundamental yang ingin menerjang mereka yang tidak mau kembali kepada pemaknaan agama secara tekstual, harus dijinakkan. Juga semangat Islam Liberal yang sangat tinggi untuk merobohkan bangunan keagamaan secara tekstual, harus dikendalikan. Dalam persepsi para aktivis Muslim, perta- rungan wacana Islam Liberal dan Fundamental ini hendaknya tidak menye- ret terlalu dalam aspek emosi dan kepentingan kelompok, melainkan justru suatu dialog pemikiran yang dinamis dan berakal sehat.

Sebab, demikian persepsi Muhtadin seorang aktivis Muslim, bukankah Islam sebagai agama rahmatan lil _alamin telah mengakomodasi semua pemikiran yang ada, bahkan tidak hanya sesama (umat) Islam, tetapi juga dengan umat non-muslim. Bukankah Islam juga sebagai agama solihun likulli zamanin wa makanin (sesuai untuk semua zaman dan tempat), tidak hanya membutuhkan teks keagamaan, tetapi juga adanya pemaknaan yang sangat kontekstual? Dan, itulah sebenarnya Islam sebagai jalan untuk mera- ih kedamaian, bukan kekerasan dan dendam untuk saling menghancurkan.

Setiap agama mengandung dua unsur penting; -dalam istilah Prof. Dr. Amin Abdullah yakni normativitas dan historitas. Secara normatif, agama berisi doktrin, ajaran yang diturunkan Tuhan untuk manusia. Karenanya, ia -sunyill dari intervensi manusia dan kebenarannya bersifat universal. Tujuan penurunan agama adalah untuk dijadikan sebagai mediasi menuju Tuhan (hablun min Allah) dan membangun hubungan baik dengan sesamanya (hablun min alnaas). Robert N. Bellah menegaskan, agama diturunkan seba- 
Konfrontasi: Jurnal Kultur, Ekonomi dan Perubahan Sosial, 1 (1) Januari 2014, 30-49

P-ISSN: 1410-881X (Print)

\section{Herdi Sahrasad, Perang Wacana Islam Liberal Versus Islam Fundamental}

DOI: -

http://www.konfrontasi.net/index.php/konfrontasi2

gai instrumen ilahiah untuk memahami dunia (2000). Ia turunkan sebagai way of life, untuk memanusiakan manusia dan sebagai problem solver atas segala persoalan yang dihadapi manusia. Jadi, agama mempu- nyai dua fungsi dan makna yang harus dilaksanakan secara sejajar, yakni makna transendental, sakral dan makna imanental, profan.

Namun secara historis, agama penuh dengan campur tangan manusia. Se- bab, agama tidak diturunkan dalam ruang hampa. Ia diturunkan dalam aneka spektrum historis-budaya tertentu, sehingga manusia mengambil bagian penting dalam agama. Sebab agama diturunkan hanya untuk ma- nusia, yakni kemaslahatan manusia. Demikianlah, Islam pun diturunkan oleh Allah SWT melalui Rasululah SAW tidak dalam kevakuman sosial- kultural. Islam bergumul dalam realitas objektif yang menyejarah, ikut mewarnai dan membentuk kebudayaan manusia. Dalam bahasa antropolog Clifford Geertz, agama bukanlah sesuatu yang otonom. Misalnya, Islam turun di Jazirah Arab yang sangat kompleks dari peradaban manusia. Di Arab ada pelbagai macam suku, agama, ras yang saling mempengaruhi dan dipengaruhi. Maka ajaran agama sangat terikat dengan kondisi dan situasi sosial setempat, bersifat temporal-partikular. Sebab agama dengan budaya setempat berdialektika secara terus-menerus. 50

Islam yang ada di Arab tentu akan berbeda (misalnya dari aspek-aspek hu- kumnya) dengan Islam yang ada di Indonesia. Maka kebenaran agama dalam optik historitas bersifat partikular.

Dalam memahami suatu agama, kedua aspek penting dari agama ini sela- yaknya dibedakan, bukan dipisahkan. Sebab, hubungan antara keduanya ibaratnya sebuah koin (mata uang) dengan dua permukaan. Kedua per- mukaan koin ini tidak bisa dipisahkan, namun bisa dibedakan. Kedua aspek tersebut bukanlah dua entitas yang berdiri sendiri dan saling berhadaphadapan, tetapi keduanya terajut dalam satu kesatuan, sehingga kedua aspek darinya tidak bisa dibuat tegang. Karena itulah, mengabaikan salah satu aspeknya berarti kita terjebak dalam salah satu ekstrem tertentu. Akibatnya, pemahaman tentang Islam tidak komprehensif, dan sepotong-sepotong. Kemudian, Islam sebagai hasil konstruksi budaya lokal yang bersifat historis juga harus ditafsirkan dalam konteks sosial dimana Islam turun. Begitupula dengan teks agama. Al-Qur'an adalah gagasan Tuhan yang diterjemahkan oleh Muhammad dalam bahasa manusia sebagai respon terhadap lokalitas yang mengitarinya saat itu tidaklah untoucable. Karena itulah tafsir ter- hadap Islam mesti beragam, sesuai dengan sejauhmana Islam dipahami. Ke- semua tafsir tersebut adalah absah dan bisa diterima manakala dikon- tekstualisasikan dengan realitas sosial yang berada di sekitarnya.

Begitu pula yang terjadi dengan pemikiran keagamaan yang belakang ini ter- lihat kontroversial. Islam Liberal tidak akan menemukan konsensus bersa- ma dalam memahami Islam dengan kalangan fundamental. Di sini Islam Fundamental akan meyakini dirinya yang benar sementara Islam Liberal adalah salah sama sekali, sehingga memerangi terhadapnya adalah salah satu bentuk ekspresi pelaksanaan ajaran agamanya, jihad (holy war).

Menarik bahwa dalam soal pluralisme, ada perbedaan interpretasi dan per- sepsi antara pihak Islam Liberal dan Fundamental. Kaum Islam Funda- mental melihat pluralisme dalam kehidupan beragama merupakan paham yang merelatifkan kebenaran agama, suatu relativisme yang berbahaya bagi keyakinan Muslim dalam menjalankan ibadah. Sedangkan kaum Liberal melihat pluralisme dalam pengertian gagasan Nurcholish Madjid, dimana pluralisme (sebagaimana yang penulis pahami) merupakan upaya mengatasi batas-batas formal agama 
Konfrontasi: Jurnal Kultur, Ekonomi dan Perubahan Sosial, 1 (1) Januari 2014, 30-49

P-ISSN: 1410-881X (Print)

Herdi Sahrasad, Perang Wacana Islam Liberal Versus Islam Fundamental

DOI: -

http://www.konfrontasi.net/index.php/konfrontasi2

sebagai intitusi untuk membangun toleransi, keadaban dan kebersamaan dalam perjuangan bersama mengatasi ketidak- adilan, kemiskinan dan keterbelakangan.

Nurcholish Madjid pernah mengemukakan bahwa pluralisme tidak dapat dipahami hanya dengan mengatakan bahwa masyarakat kita majemuk, bera- neka ragam, terdiri dari berbagai suku dan agama, yang justru hanya meng- gambarkan kesan fragmentasi, bukanlah pluralisme. Pluralisme juga tidak boleh dipahami sekedar sebagai = kebaikan negatif", hanya ditilik dari kegu- naannya untuk menyingkirkan fanatisisme. Pluralisme harus dipahami seba- gai -pertalian sejati kebhinekaan dalam ikatan-ikatan keadaban“". Bahkan pluralisme adalah juga suatu keharusan bagi keselamatan umat manusia, antara lain melalui mekanisme pengawasan dan pengimbangan yang dihasil- kannya. Dalam kitab suci Al-Qur'an justru disebutkan bahwa Allah men- ciptakan mekanisme pengawasan dan pengimbangan di antara sesama manusia guna memelihara keutuhan bumi dan merupakan salah satu wujud kemurahan Tuhan yang melimpah kepada umat manusia," Seandainya Allah tidak mengimbangi segolongan manusia dengan segolongan yang lain, maka pastilah bumi hancur, namun Allah mempunyai kemurahan yang melimpah kepada seluruh alam." (QS. 2:251). 56 Karena itu, pluralisme merupakan bagian dari keimanan yang paling inti. Namun demikian, pema- haman dan pengertian tentang pluralisme ini masih menjadi perdebatan di kalangan Islam Liberal dan Fundamental di Indonesia.

Dalam persepsi Ahmad Sahal, sejarah liberalisme adalah sejarah kebebasan individu modern dan pembebasannya dari absolutisme kekuasaan. Sejak akhir abad ke-17, seiring dengan makin kokohnya perdagangan dan pence- rahan di tanah Eropa, muncul kesadaran di kalangan masyarakat Barat akan pentingnya kebebasan individu, dan mereka telah letih dengan perang aga- ma dan pengap dengan despotisme ancient regime.57 Akan tetapi pandangan Sahal bahwa penjumlahan dari liberalisme dan sekularisme adalah demo- krasi,58 mengesankan ia melakukan simplifikasi yang cenderung mengun- dang kegusaran sekaligus memperkuat ketidakpahaman kaum Muslim fun- damental bahwa demorkasi liberal tidak sesuai dengan ajaran Islam, dan bahwa seolah-olah Islam tidak memiliki sumber rujukan nilai dan inspirasi bagi demokrasi. Padahal, tradisi Islam sejak zaman Rasullulah sudah me- ngenal adanya demokrasi (syura) dan negara modern sebagaimana dalam kasus Negara Madinah hingga era Kekhalifahan bahkan sampai era Cordova (Spain of three religion). Abdurrahman Wahid dan Nurcholish Madjid sa- ngat mengapresiasi sejarah pengalaman Negara Madinah (dengan Piagam Madinahnya) sebagai model -demokrasi konstitusionalisme" dalam Islam di masa awal perkembangan Islam dalam membangun kehidupan kenegaraan di tengah masyarakat yang plural, majemuk.

Kenyataan akan fatwa MUI dan kontra-fatwa itu menunjukkan bahwa pe- rang urat syaraf antara Islam Liberal dan Islam Fundamental (literal) di Indonesia telah menyeruak dan terus berjalan, untuk berebut pengaruh di ruang politik dan sosial-kultural dengan segala implikasinya. Persaingan kedua arus Islam itu juga menimbulkan kritik dari kalangan Muslim taat yang tidak terlibat dalam rivalitas kedua paham tersebut, terutama kritik tentang seberapa jauh komitmen Islam Liberal dan Fundamental untuk mengatasi kemiskinan, ketidakadilan dan ketertindasan ummat di tengah menguatnya neo-liberalisme di Indonesia. Juga seberapa jauh -peran dan kerja nyatall kedua kalangan Islam itu bagi pemberdayaan ummat yang ter- tinggal, lemah dan termarginalkan oleh modernisme yang jelas bias mate- rial, bias modal dan bias Barat. 
Konfrontasi: Jurnal Kultur, Ekonomi dan Perubahan Sosial, 1 (1) Januari 2014, 30-49

P-ISSN: 1410-881X (Print)

\section{Herdi Sahrasad, Perang Wacana Islam Liberal Versus Islam Fundamental}

DOI: -

http://www.konfrontasi.net/index.php/konfrontasi2

Para Muslim moderat berpendapat bahwa menuding bahwa fatwa MUI akan menghantam dasar-dasar demokrasi (liberal) di Indonesia, mungkin berle- bihan, namun bereaksi untuk mengutuk pembaruan pemikiran Islam juga tidak memecahkan persoalan dan malah meningkatkan suhu pertengkaran dan ketegangan antar umat Islam.

Dalam konteks ini, ada gejala serupa dengan kontroversi fatwa MUI -meski- pun tidak banyak diberitakan media massa-, yakni sebuah diskusi buku karya Hartono Ahmad Jaiz yang berjudul Ada Pemurtadan di IAIN yang berlangsung di UIN Syarif Hidayatullah Jakarta, tahun 2004 yang menun- jukkan dengan gamblang adanya -perang pemikiran\|l Islam Liberal versus Fundamental secara sarkastis-antagonistis, suatu isyarat benderang adanya persaingan berebut ruang sosial-kultural dari kedua belah pihak. Bahkan tak lama kemudian, dalam Kongres Umat Islam Indonesia (KUII) IV di Jakarta merekomendasikan agar MUI mengeluarkan fatwa untuk melarang gerakan Islam yang mengusung ide-ide sekularisme, pluralisme dan liberalisme di Indonesia. Lebih jauh, di sejumlah mailing list bahkan muncul ancaman mati dan penghalalan darah bagi para pendukung gagasan Islam Liberal.

Kenyataan seperti ini, dengan mudah, bisa diduga terjadi oleh adanya penaf- siran yang berbeda terhadap Islam. Bahwa Islam dipahami sebagai ajaran tunggal yang hanya mengenal interpretasi tunggal. Lebih lanjut, keyakinan bahwa hanya ada interpretasi tunggal yang benar atas Islam ini kemudian memunculkan klaim kebenaran sepihak dan pada saat bersamaan mena- fikan kebenaran kelompok lain. Gejala seperti ini memang sama sekali bu- kan hal baru dalam sejarah perkembangan pemikiran Islam di dunia. Pasang surut $\mathrm{Mu}$ 'tazilah sebagai faham resmi dan faham yang ditentang oleh negara, peristiwa yang dialami oleh sejumlah intelektual Muslim di Timur Tengah, dari Ali Abd al-Raziq, Ahmad Khalafullah sampai Nasr Hamid Abu Zaid, hijrahnya Fazlur Rahman dari negeri asalnya, Pakistan menuju Amerika Serikat, menjadi saksi sejarah yang nyata.

Bagaimanapun tafsir tunggal kebenaran Islam sangatlah berbahaya karena bisa menimbulkan monopoli politik dan kekuasaan atas nama agama, seba- gaimana pernah terjadi di masa lampau dalam pengalaman di Timur Tengah era dinasti kekhalifahan.

Klaim sebagai pemilik kebenaran tunggal Islam bisa terjadi karena para pendukung gagasan kebenaran tunggal Islam umumnya berada pada posisi yang menganggap seluruh dimensi dalam Islam bersifat -dalam bahasa Arkoun- unthought dan unthinkable. Jika bidang yang tak terfikirkan ini dikem- bangkan dan diperluas dalam sebuah tradisi pemikiran partikular, maka horizon nalar intelektual akan mengalami ancaman dan fungsi kritisnya mengalami penyempitan dan melemah, karena ruang yang bisa dipikirkan menjadi sangat ketat dan hanya tersisa sedikit ruang yang terbuka bagi penafsiran (Arkoun, 2003). Tidak bisa dipungkiri, unthought ini, lanjut Ar- koun, terbentuk dari sejumlah isu yang terakumulasi yang kemudian dinya- takan sebagai unthinkable dalam sebuah logosphere yang sudah given. Oleh Arkoun, logosphere diformulasikan sebagai ruang mental kebahasaan yang digunakan secara bersama-sama oleh sekelompok orang yang menggu- nakan bahasa yang sama untuk mengartikulasikan pemikiran-pemikiran, penggambaran, memori kolektif dan pengetahuan mereka berdasarkan pada prinsip-prinsip dan nilai-nilai fundamental yang diklaim sebagai unifying weltanschaung.

Islam adalah agama dan pandangan hidup yang telah melahirkan peradaban yang gemilang di zaman Rasululah dan para khalifah. Untuk memperta- hankan dan mengembangan peradaban Islam tidak berarti menolak men- tah-mentah masuknya unsur- 
Konfrontasi: Jurnal Kultur, Ekonomi dan Perubahan Sosial, 1 (1) Januari 2014, 30-49

P-ISSN: 1410-881X (Print)

\section{Herdi Sahrasad, Perang Wacana Islam Liberal Versus Islam Fundamental}

DOI: -

http://www.konfrontasi.net/index.php/konfrontasi2

unsur peradaban asing. Sebaliknya untuk ber- sikap adil terhadap peradaban lain tidak berarti bersikap permisif terhadap masuknya segala macam unsur dari peradaban lain tanpa proses adaptasi dan akulturasi.

Dalam hal ini, bisa dipahami pandangan Pradana Boy, dosen Universitas Muhammadiyah Malang (UMM) yang sedang menempuh studi di ANU Can- berra, bahwa dengan adanya kesadaran progressive-regressive dalam kon- teks perdebatan Islam Fundamental dan Liberal ini, akan terbentang sebuah fakta bahwa pencarian kebenaran Islam sepanjang sejarah agama ini, mela- hirkan kebenaran yang tidak tunggal.

Tidak tunggalnya kebenaran ini, bukan menunjukkan bahwa Islam menga- lami reduksi pemaknaan atau Islam semakin jauh dari sumbernya, tetapi justru menampakkan betapa Islam telah terbukti sebagai agama yang durable dan mampu memasuki relung-relung zaman tanpa kehilangan aktu- alitasnya.

Karena itu, dalam menghadapi Islam Liberal, publik harus mendorong Adian Husaini, Adnin Armas, Hamid F. Zarkasyi dan kawan-kawan di kubu Islam Fundamental bersikap secara intelektual atas Kelompok Pembaharuan bersama aneka jenis keturunannya dari kelompok Islam Liberal sampai pencinta Hermeneutika, yang semua itu harus dihadapi secara memadai dengan ilmu pengetahuan yang mengimbangi mereka, secara santun dan elegan, jauh dari sikap emosional dan brutal. Sebaliknya, Islam Liberal pun dalam merespon Islam Fundamental seyogianya tidak bersikap reaksioner dan mengesankan kegenitan intelektual.

Dalam konteks modernitas, apa yang diperlukan memang bukan semata- mata penafsiran yang progresif terhadap Islam, tetapi juga mempertim- bangkan masa lalu sebagai sumber inspirasi untuk mencapai kebenaran Islam. Arkoun mengistilahkannya sebagai metode progressive-regressive. Dengan metode ini yang dimaksudkan oleh Arkoun adalah penggabungan perspektif historis jangka panjang dengan perspektif jangka pendek, sebab semua bentuk diskursus kontemporer yang lahir dalam konteks Islam, nis- caya selalu merujuk kepada periode awal Islam dan -Golden Agell peradaban Islam yang digunakan sebagai referensi mitologis untuk mengaktifkan dan menghadirkan kembali nilai dalam bentuk paradigma etis dan hukum, yang perlu diuji kembali berdasarkan prinsip -kritik nalar Islam.॥

Pada akhirnya, saya kira benar prediksi pemikir dan akademisi Yudi Latif Ph.D64 bahwa di Indonesia sekarang dan masa depan, percaturan wacana Islam dalam memperebutkan ruang politik dan sosial-kultural bagi -aspirasi, kepentingan dan cita-citall masing-masing, akan tergantung kepada sebe- rapa jauh kekuatan modal sosial-kultural dan modal ekonomi dari kalangan Islam Liberal dan Fundamental dalam berlomba untuk merebut ruang sosial dan politik. Juga dalam menegakkan kebajikan sosial dan keadaban. Perca- turan wacana itu akan lebih banyak diwarnai oleh lingkaran Adian Husaini cs dan Ulil Abshar Abdalla cs yang banyak mengisi ruang publik generasi saat ini, dengan karakter, metode, cara, langgam dan epistemologi masing- masing, yang sangat mungkin cenderung mengarah kepada

'moderasi' " mengingat perkembangan peradaban ummat manusia yang bergerak cepat- pesat akibat derasnya pragmatisme, modernisme,dan globalisme yang mem- bawa panji-panji demokrasi dan pluralisme, saling imbang dan saling kon- trol, di tengah kompleksitas dunia yang terus berubah. Pertarungan Islam Liberal versus Fundamental dalam berebut struktur peluang politik dan ruang publik masih akan berlangsung lama dan belum ada titik terang apakah proyek Islamisme ini akan terus berlanjut atau justru buntu di tengah jalan. Wallahualam bissawab. 
Konfrontasi: Jurnal Kultur, Ekonomi dan Perubahan Sosial, 1 (1) Januari 2014, 30-49

P-ISSN: $1410-881 X$ (Print)

Herdi Sahrasad, Perang Wacana Islam Liberal Versus Islam Fundamental

DOI: -

http://www.konfrontasi.net/index.php/konfrontasi2

\section{Bibliografi}

-Gado-Gado Islam Liberal,\|l Sabili, No. 15, Thn IX/2001.

-Ulama Dihina, Tumpas Gerombolan Liberall, Majalah Sabili, No. 3, Tahun XIII, 25 Agustus 2005.

Abdalla, Abshar, Ulil dan Sahrasad, Herdi, -Meruntuhkan Hegemoni Tafsir, Menghidupkan Kembali Teks,\| Ulumul Quran, Nomor 3 Vol.5 tahun 1994.

Abdalla, Abshar, Ulil, dkk, Islam Liberal dan Fundamental: Sebuah Pertarungan Wacana (Yogyakarta: Elsaq, 2003).

Adian Husaini, -Paradoks Kebangkitan Islam,\|www.icmi.org, diakses pada 20 Desember 2004.

Al Qurtuby, Sumanto, -Quo Vadis Jaringan Islam Liberal?,\|I Islamlib.com, 10 maret 2005.

Arifin, Syamsul, -Menakar Otentitas Islam Liberal,॥ Jawa Pos, 1 Februari 2000.

Arkoun, Muhammad, Aina Huwal Fikrul Islamy Al-Mu'ashir (Beirut: Darus Saqi, 1993).

Barton, Greg, Gagasan Islam Liberal di Indonesia (Jakarta: Pustaka Antara Paramadina, 1999).

Bashori, Agus Hasan, -Bahaya Islam Liberal॥, Risalah, 22 April 2004.

Boy ZTF, Pradana, -Orientalisme dan Dialog AntarKitab,„ Paper (Canberra: ANU, 2004).

Brumberg, Daniel, -Islam, Elections and Reform in Algeria,ll Journal of Democracy, Vol. 2, Musim Dingin 1991

Gazali, Hatim, -Menyikapi Hal Yang Dianggap Benar,\| Wacana, 6 Juli 2004.

Keck and Sikkink, Activists Beyond Borders: Transnational Advocacy Networks in International Politics (Ithaca: Cornell University Press, 1998).

Kurzman Charles, (ed), Wacana Islam Liberal, (Jakarta:Paramadina, 2001). Kurzman, Charles (ed.), Liberal Islam, A Sourcebook (Oxford University

Press, 1998).

Kurzman, Charles —Pengantar, $\|$ dalam Islam Liberal dan Konteks Islaminya

(Jakarta: Paramadina, 2001).

Latif, Yudi, -Kejarangan Membawa Nilai“‘, Kompas, 2 Juli 2005.

Lewis, Bernard, What Went Wrong? Western Impact and Middle Eastern Response

(London: Phoenix, 2002)

Maruih, Sufandi, —Dialog Dengan Aktivis JIL,\| Harian Terbit, 30 Januari 2004.

Mu'adz, Muhammad Arkoun, -Anggitan Tentang Cara-Cara Tafsir Al- Qur'an,॥ Jurnal Salam, vol.3 No. 1/2000.

Muhtadin AR, -Islam Jalan Damai“", Media Indonesia 7 Januari 2003. Rachman, Munawar, Budhy, -Perjumpaan Kristen-Islam perlu Toleransi

Sejati“ “, Kompas 20 Agustus 2005.

S. Karni, Asrori, -Komunitas\|, GATRA, 17 Nopember 2003.

Sahal, Ahmad, -MUI dan Fatwa Antidemokrasi,॥ Tempo, 21 Agustus 2005. Suhelmi, Ahmad, Pemikiran Politik Barat (Jakarta: Gramedia, 2001).

Tarrow, Sidney, Power in Movement: Social Movements and Contentious Politics (Cambridge University Press, 1998). 